
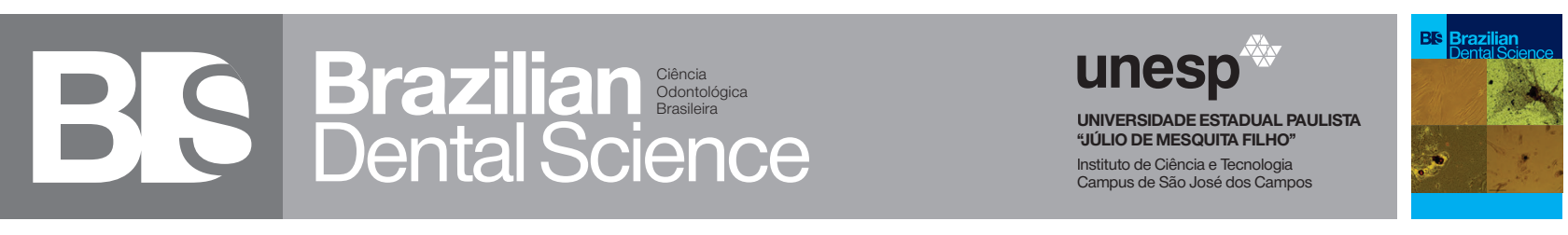

\title{
Clinical and radiographic evaluation of Curcumin Gel mixed Endoflas (CGE) powder as obturating material in primary molars
}

\author{
Avaliação clínica e radiográfica do pasta de curcumina Endoflas (CGE) como material obturador em molares decíduos
}

Alekhya Chowdary MENNI' ${ }^{1}$, Naga Radhakrishna AMBATI ${ }^{1}$, Madu Ghanashyam PRASAD ${ }^{1}$

1 - Department of Pedodontics\&Preventive Dentistry - St.Joseph Dental College - Duggirala - Eluru - Andhrapradesh - India

\begin{abstract}
Background: Zinc oxide eugenol(ZOE) has long been the material of choice for obturating primary teeth,but it is resistant to resorption, might result in a deflected successor and has limited antibacterial efficacy. Curcuminpossessesanti-inflammatory and antimicrobialproperties which can be implied by its use as obturating material in primary teeth. Objective: To evaluate and compare the efficacy of Curcumin Gel mixed Endoflas powderand Zinc oxide eugenol as obturating materials in primary molars. Material and methods: A total of 30 primary molars indicated for pulpectomy were selected from 4-9-yearold children and divided into two equal groups based on the obturating material used. Group 1- Curcumin Gel mixed Endoflas powder(CGE) and Group 2Zinc oxide eugenol(ZOE). The efficacy of these obturation materials was evaluatedboth clinically and radiographically. Follow-up was done after 1, 3 and 6 months to evaluate clinical and radiographical success rates. The results were subjected to statistical analysis using SPSS software version 21 using chisquare test. Results: At the end of the $6^{\text {th }}$ month follow-up,there was $93.3 \%$ clinical success in Group 1 compared with $86.6 \%$ success in Group 2 . Whereas, radiographically success reported was $100 \%$ with Group 1 and 93.3\% with Group 2. The difference in the radiographic success rate between the two Groups was statistically significant $(P<0.05)$. Conclusion: Based on the present study results, Curcumin Gel mixed Endoflas powder can be considered as an alternative obturation material for treating deciduous molars with extensive involvement of pulp and periradicular tissues.
\end{abstract}

\section{KEYWORDS}

Pulpectomy; Obturating materials; Endoflas; Antimicrobials; Turmeric; Zinc oxide eugenol.

\section{RESUMO}

Fundamentação: O óxido de zinco eugenol (OZE) há muito tempo é o material de escolha para a obturação de dentes decíduos, mas é resistente à reabsorção, podendo resultar em um dente permanente desviado e tem eficácia antibacteriana limitada. A curcumina possui propriedades anti-inflamatórias e antimicrobianas que podem indicar seu emprego como material obturador em dentes decíduos. Objetivo: Avaliar e comparar a eficácia da pasta de curcumina Endoflas e do óxido de zinco eugenol como materiais obturadores em molares decíduos. Material e métodos: Um total de 30 molares decíduos indicados para pulpectomia foram selecionados entre crianças de 4 a 9 anos e divididos em dois grupos iguais, com base no material obturador utilizado. Grupo 1 - pasta de curcumina Endoflas (CGE) e Grupo 2- óxido de zinco eugenol (ZOE). A eficácia desses materiais de obturação foi avaliada clinicamente e radiograficamente. O acompanhamento foi realizado após 1, 3 e 6 meses para avaliar as taxas de sucesso clínico e radiográfico. Os resultados foram submetidos à análise estatística no software SPSS versão 21, utilizando o teste quiquadrado. Resultados: No final do sexto mês de acompanhamento, houve $93,3 \%$ de sucesso clínico no Grupo 1 em comparação com 86,6\% de sucesso no Grupo 2. Considerando que, o sucesso radiográfico relatado foi de 100\% no Grupo 1 e 93,3\% no Grupo 2. A diferença na taxa de sucesso radiográfico entre os dois grupos foi estatisticamente significante $(P<0,05)$. Conclusão: Com base nos resultados do presente estudo, a pasta de curcumina Endoflas pode ser considerada como um material de obturação alternativo para o tratamento de molares decíduos com amplo envolvimento de polpa e tecidos perirradiculares.

\section{PALAVRAS-CHAVE}

Pulpectomia; Materiais obturadores; Endoflas; Antimicrobianos; Curcuma; Óxido de zinco eugenol. 


\section{INTRODUCTION}

$\mathrm{T}_{\mathrm{i}}^{\mathrm{h}}$ he primary objective of pulp therapy is to preserve the integrity and health of the teeth and their supporting tissues. Pulpectomy is a root canal procedure for pulp tissue that is irreversibly infected or necrotic due to caries or trauma. Pulpectomy technique on deciduous dentition has several obstacles, such as molar root curvature, root canal complexity and physiological resorption [1].The success of endodontic therapy relies directly on the accurate accomplishment of all operative procedures, strict compliance with the specific treatment guidelines, and the choice ofbiocompatible materials. In addition, the filling material must fulfill the accepted triad of treatment goals, namely removal of diseased tissue, elimination or reduction of bacteria and prevention of canal reinfection. Theroot canal filling material must be biocompatible and protected with a well-sealed coronal restoration [2].

Till date, numerous materials such as Zinc oxide eugenol (ZOE), calcium hydroxide, calcium hydroxide with iodoform paste, Guedes-Pinto paste ( a drug combination composed of Iodoform, Rifocort ${ }^{\circledR}$ ointment and Camphorated Paramonochlorophenol (CPC) [3],KRI paste, Maisto's paste, Walkhoff's paste, etc. have been tested for their efficiency as root canal filling materials, but none of these have shown to possess all the requisite properties of an ideal root canal filling material for primary teeth, especially with regard to the major desirable property of having a rate of resorption matching that of the physiologic root resorption of the primary teeth [4].

Due to untoward reactions elicited by these materials like being irritating to the tissues and triggering foreign-body reactions within the periapical tissues, particularly when extruded beyond apex has limited their use [2].Amongthem,Zinc oxide and eugenol cement (ZOE) has been widely used in the primary dentition. The shortcoming that has restricted the use of this compound is its low resorption capacity, due to which zinc oxide and eugenol particles are left within the periapical tissues as the physiological root resorption occurs [2].

Endoflas had a high success rate and was considered to be an effective root canal filling material in primary teeth due to its healing ability, bone regeneration characteristics and its resorption of excess material without washing within the roots [5].But the main disadvantage with Endoflas (triiodomethane, Zinc oxide, calcium hydroxide, barium sulphate, and iodine di-btiloorthocresol, with the liquid consisting of eugenol and paramonochlorophenol)[6] is eugenol which is known to cause periapical irritation [7].

In thismodern era of dentistry, we are looking toward herbal alternatives suchas extracts of plant origin that have therapeutic properties and in usagefor thousands of years. There are many advantages of using herbs as antimicrobials: (a) They have fewer side effects; (b) less expensive; (c) better patient tolerance, and (d) renewable in nature [8] Turmeric is a natural medicament with a wide spectrum of biologic actions which include antiinflammatory, anti-oxidant, anti-carcinogenic, anti-mutagenic, antibacterial and antifungal properties.Curcumin (diferuloylmethane) the main yellow bioactive component of turmeric has a wide spectrum of biological actions and this provides a basis for exploring its use in endodontic applications [9].

In the present study, for additive effect and to overcome the limitations of eugenol in Endoflas, Curcumin Gel mixed with Endoflas powder (CGE)was compared to Zinc oxide eugenolas obturating material in primary molars.

\section{MATERIAL AND METHODS}

This study was conducted at Department of Pedodontics and Preventive Dentistry, St. Joseph Dental College, Andhra Pradesh, India. It was approved by the Institutional 
EthicalCommittee; [Protocol/IRB/21/201518] informed written consent was obtained from all participating children'sparents/ legal guardians. Thirty primary molars(24 mandibular and6 maxillary molars)from 28 healthy, normal children (16 boys and 12 girls) aged 4-9 years meeting the inclusion criteria were selected for the study and pulpectomy procedure was carried out under local anesthesia.The sample size was determined with confidence level of $95 \%$ and with a margin of error of $5 \%$.

Inclusion criteria: 1) History of spontaneous pain 2) Presence of an abscess or a fistula 3) Tenderness on percussion and 4) Radiograph revealing interradicular radiolucency [3]

Exclusion criteria: 1) Obliteration of the root canal; 2) Internal resorption; 3) Physiologic root resorption with more thantwo-thirds of its length[3] and 4) Special children

The selected teeth were randomly divided into two groups of 15 each(Figure1).

Group 1: Curcumin Gel mixed Endoflas powder (CGE)

\section{Group 2: Zinc Oxide Eugenol (ZOE)}

Preparation of the curcumin gel mixed endoflas powder (Cge)

A ratio of 1:3 Curcumin gel (Curenext oral gel, ABBOTT India Limited) to Endoflas powder was mixed on a glass slab with stainless steel spatula, by incorporating the Endoflas powder into Curcumin gel in increments, using the folding technique into a thick mix.
Single visit pulpectomies for both the groups were performed by a singleoperator. Basic behavior techniques were applied to all the children in the present study.The pulpectomy procedure was carried out using a rubber dam after administration of local anesthesia. The access to the chamber was obtained using BR40 bur after removal of the carious tooth structure. The coronal pulp was removed with a spoon excavator. An intraoral periapical radiograph was taken to confirm the working length during the procedure. Irrigation was carried out using $2.5 \%$ (20ml) sodium hypochlorite alternatively with saline. Biomechanical preparation was done with $21 \mathrm{~mm} \mathrm{k}$ files usingstep-back technique. Paper points were used for drying the canalsprior to obturation. Incremental obturation technique was followed to obturate the canals with CGE in group 1(Figure 1a, 1b) and ZOE in group 2(Figure 2a, 2b).Post obturation access cavity was restored with GC Gold Label Type IX (GC Corporation, Tokyo, Japan) glass ionomer cementfollowed by placement of stainless steel crown (Figure 1c,2c).

Clinical and radiographic evaluations were done by two evaluators who were blinded to the obturation material used after 1,3 , and 6 month's postoperative period(Figure $1 \mathrm{~d}, 1 \mathrm{e}, 2 \mathrm{~d}, 2 \mathrm{e})$. Clinically treatment was considered successful when there was absence of pain, swelling, tenderness on percussion and mobility. Radiographically, the treatment was considered successful when there was no interradicular radiolucency, absence of internal resorption, no deviated path of eruption of permanent successors and resorption of the material in conjunction with the root resorption. 


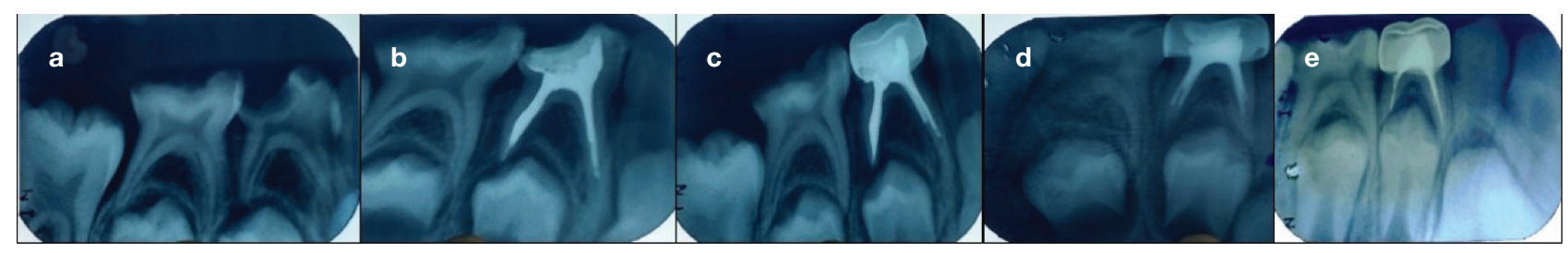

Figure 1- a: CGE Group I. b: Tooth\# 84 pre op. c: 1 month.d: 3months. e: 6 months follow-up.

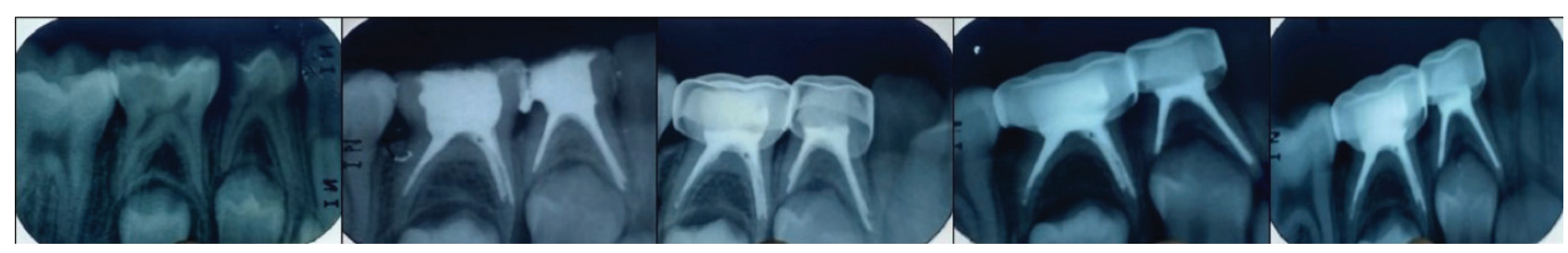

Figure 2- a: ZOE Group I Tooth no 84,85 pre op. b: Immediate post op. c: 1 month. d: 3 months. e: 6 months follow-up.

\section{Statistical analysis}

The obtained data were subjected to statistical analysis using statistical package for social sciences (SPSS) software Version 21. Chi-squaretest was applied between the time points in each group and between two groups.

\section{RESULTS}

The preoperative and postoperative clinical signs and symptoms were tabulated. Statistically significant difference $(P=0.0001)$ was seen between the preoperative and postoperative clinical signs and symptoms in both the Groups at postoperative 1, 3 and 6 months. There were no extractions in both the groups. But, two teeth had shown pain in Group 2 [Zinc oxide eugenol(ZOE)] at the end of $6^{\text {th }}$ month follow-up, the clinical success of zinc oxide eugenol (ZOE)was $86.6 \%$, whereas the clinical success rate was $100 \%$ for Curcumin Gelmixed Endoflas powderGroup (CGE) (Table 1).

In Group 1, radiographically, interradicular radiolucency was present in 8 teeth preoperatively. Bythe end of 1-month follow-up,inter radicular radiolucency was observed in two primary molars and at $3^{\text {rd }}$ month follow-upall the teeth displayed complete resolution of radiolucency.All the teeth displayednointer radicular radiolucency at the end of $6^{\text {th }}$ month follow-up $(p=0.001)$. Neitherinternal resorption nordeviated path of eruption of succedaneousteeth was noted at the end of 6 months in both the groups. Whereas in Group 2 [zinc oxide eugenol $(\mathrm{ZOE})]$ there were no changes in interradicular radiolucencypreoperatively and no deviated path of eruption of succedaneous teeth wereobserved in all follow-ups(Table 2).

Radiographic assessment of the overfilled material in Group 1 revealed that out of the 6 (40\%) overfilled teeth, complete resorption of the excess material was seen in all the $6(40 \%)$ teeth at the end of 1 month follow-up period. Whereas in Group 2, 1 (6.6\%) tooth showed overfilled material and at the end of the6th month follow-up there was no resorption of the overfilled material(Table 3).

Radiographic assessment of resorption of the filling material with physiologic root resorption revealed that in Group 1 resorption of rootless than filling material was seen in 3 (19\%) teeth at the end of 1 month follow-up and in $5(33.3 \%)$ teeth at the end of $3^{\text {rd }}$ and $6^{\text {th }}$-month follow-up. Resorption of the root equal to fillingmaterial resorption in 12 (79\%) teeth at the end of 1-month follow-up and 10 $(66.6 \%)$ teeth at theend of $3^{\text {rd }}$ and $6^{\text {th }}$-month follow-up. In Group 2[zinc oxide eugenol 
(ZOE)], resorption of theroot greater than the filling material in one $(6.6 \%)$ toothwas observed at the end of 6th-month follow-up. Resorption of theroot equal to filling material resorption in $14(93.3 \%)$ teeth at the end of the $6^{\text {th }}$ month was observed(Table 4).

The overall clinical and radiographic findings in this study revealed 100\% clinical success in Group 1compared with 86.6\% success in Group 2. Whereas, radiographically success reported was 100\% in Group 1 and $93.3 \%$ in Group 2 at the end of 6 months follow-up(Table 5).

Table 1 - Comparison of group 1 \& 2 clinical findings

\begin{tabular}{|c|c|c|c|c|c|c|c|c|}
\hline \multirow{2}{*}{$\begin{array}{c}\text { Follow- } \\
\text { up } \\
\text { period }\end{array}$} & \multicolumn{2}{|c|}{ Pain } & \multicolumn{2}{|c|}{ Mobility } & \multicolumn{2}{|c|}{ Swelling } & \multicolumn{2}{|c|}{$\begin{array}{c}\text { Tenderness } \\
\text { on } \\
\text { percussion }\end{array}$} \\
\hline & $\begin{array}{c}\text { Group } \\
1 \\
n \%\end{array}$ & $\begin{array}{c}\text { Group } \\
\mathbf{2} \\
\mathbf{n} \%\end{array}$ & $\begin{array}{c}\text { Group } \\
1 \\
\mathrm{n} \%\end{array}$ & $\begin{array}{c}\text { Group } \\
2 \\
n \%\end{array}$ & $\begin{array}{c}\text { Group } \\
1 \\
n \%\end{array}$ & $\begin{array}{c}\text { Group } \\
2 \\
\mathbf{n} \%\end{array}$ & $\begin{array}{c}\text { Group } \\
1 \\
n \%\end{array}$ & $\begin{array}{c}\text { Group } \\
\mathbf{2} \\
\mathrm{n} \%\end{array}$ \\
\hline $\begin{array}{l}\text { Pre-opera- } \\
\text { tive }\end{array}$ & $\begin{array}{c}15 \\
100 \%\end{array}$ & $\begin{array}{c}15 \\
100 \%\end{array}$ & $\begin{array}{c}1 \\
6.6 \%\end{array}$ & $\begin{array}{c}0 \\
0 \%\end{array}$ & $\begin{array}{c}1 \\
6.6 \%\end{array}$ & $\begin{array}{c}0 \\
0 \%\end{array}$ & $\begin{array}{c}4 \\
26.7 \%\end{array}$ & $\begin{array}{c}7 \\
46.7 \%\end{array}$ \\
\hline 1month & 0 & $\begin{array}{c}2 \\
13.3 \%\end{array}$ & 0 & 0 & 0 & 0 & 0 & $\begin{array}{c}2 \\
13.3 \%\end{array}$ \\
\hline 3 months & 0 & $\begin{array}{c}2 \\
13.3 \%\end{array}$ & 0 & 0 & 0 & 0 & 0 & $\begin{array}{c}2 \\
13.3 \%\end{array}$ \\
\hline 6 months & 0 & $\begin{array}{c}2 \\
13.3 \%\end{array}$ & 0 & 0 & 0 & 0 & 0 & $\begin{array}{c}2 \\
13.3 \%\end{array}$ \\
\hline Pvalue & 0.0001 & 0.0001 & 0.399 & - & 0.399 & - & 0.002 & 0.002 \\
\hline
\end{tabular}

${ }^{*}$ chi-square test was applied to determine the success rate between both groups.

Table 2 - Comparisons of group $1 \& 2$ radiological findings

\begin{tabular}{|c|c|c|c|c|c|c|}
\hline $\begin{array}{l}\text { Radiological signs and } \\
\text { symptoms }\end{array}$ & \multicolumn{3}{|c|}{ Group1 } & \multicolumn{3}{|c|}{ Group2 } \\
\hline \multirow{2}{*}{$\begin{array}{l}\text { Pre-Operative Furcation } \\
\text { Radiolucency }\end{array}$} & \multicolumn{3}{|c|}{$\mathrm{n}(\%)$} & \multicolumn{3}{|c|}{$n(\%)$} \\
\hline & \multicolumn{3}{|c|}{ 8(53.3\%) } & \multicolumn{3}{|c|}{$\mathbf{0}(0 \%)$} \\
\hline & $\begin{array}{c}1 \\
\text { month }\end{array}$ & $\begin{array}{c}3 \\
\text { months }\end{array}$ & $\begin{array}{c}6 \\
\text { months }\end{array}$ & $\begin{array}{c}1 \\
\text { month }\end{array}$ & $\begin{array}{c}3 \\
\text { months }\end{array}$ & $\begin{array}{c}6 \\
\text { months }\end{array}$ \\
\hline $\begin{array}{l}\text { Post-Operative Furcation } \\
\text { Radiolucency }\end{array}$ & $\begin{array}{c}n \\
(\%) \\
2 \\
(13.3 \%)\end{array}$ & $\begin{array}{c}n \\
(\%) \\
0 \\
(0 \%)\end{array}$ & $\begin{array}{c}n \\
(\%) \\
0 \\
(0 \%)\end{array}$ & $\begin{array}{c}n \\
(\%) \\
0 \\
(0 \%)\end{array}$ & $\begin{array}{c}n \\
(\%) \\
0 \\
(0 \%)\end{array}$ & $\begin{array}{c}\mathrm{n} \\
(\%) \\
0 \\
(0 \%)\end{array}$ \\
\hline Pvalue & 0.001 & - & - & - & - & - \\
\hline Internal resorption & $\begin{array}{c}0 \\
(0 \%)\end{array}$ & $\begin{array}{c}0 \\
(0 \%)\end{array}$ & $\begin{array}{c}0 \\
(0 \%)\end{array}$ & $\begin{array}{l}0 \\
(0 \%)\end{array}$ & $\begin{array}{c}0 \\
(0 \%)\end{array}$ & $\begin{array}{c}0 \\
(0 \%)\end{array}$ \\
\hline Pvalue & - & - & - & - & - & - \\
\hline $\begin{array}{l}\text { Deviated path of eruption of } \\
\text { succedaneous teeth }\end{array}$ & $\begin{array}{c}0 \\
(0 \%)\end{array}$ & $\begin{array}{c}0 \\
(0 \%)\end{array}$ & $\begin{array}{c}0 \\
(0 \%)\end{array}$ & $\begin{array}{c}0 \\
(0 \%)\end{array}$ & $\begin{array}{c}0 \\
(0 \%)\end{array}$ & $\begin{array}{c}0 \\
(0 \%)\end{array}$ \\
\hline Pvalue & - & - & - & - & - & - \\
\hline
\end{tabular}

${ }^{*}$ Chi-square test was applied to determine the success rate between the groups
Table 3 - Comparison of postoperative relative resorption of filling material with respect to root resorption at 6 months in group 1 and 2

\begin{tabular}{|c|c|c|c|c|c|c|c|}
\hline \multirow{3}{*}{ GROUPS } & \multirow{3}{*}{$\begin{array}{l}\text { RESORPTION } \\
\text { OF MATERIAL IN } \\
\text { RELATION TOROOT } \\
\text { RESORPTION }\end{array}$} & \multicolumn{6}{|c|}{ FOLLOW-UP PERIOD } \\
\hline & & \multicolumn{2}{|c|}{ 1month } & \multicolumn{2}{|c|}{ 3months } & \multicolumn{2}{|c|}{ 6months } \\
\hline & & $\mathrm{n}$ & $\%$ & $\mathrm{n}$ & $\%$ & $n$ & $\%$ \\
\hline \multirow{4}{*}{ Group1 } & $\begin{array}{l}\text { Resorption of root greater } \\
\text { than filling material }\end{array}$ & 0 & $0 \%$ & 0 & $0 \%$ & 0 & $0 \%$ \\
\hline & $\begin{array}{l}\text { Resorption of root equal to } \\
\text { filling material }\end{array}$ & 12 & $79 \%$ & 10 & $66 \%$ & 10 & $66 \%$ \\
\hline & $\begin{array}{l}\text { Resorption of root less } \\
\text { than filling material }\end{array}$ & 3 & $19 \%$ & 5 & $33.3 \%$ & 5 & $33.3 \%$ \\
\hline & Pvalue & \multicolumn{6}{|c|}{0.02} \\
\hline \multirow{4}{*}{ Group2 } & $\begin{array}{l}\text { Resorption of root greater } \\
\text { than filling material }\end{array}$ & 1 & $6.6 \%$ & 1 & $6.6 \%$ & 1 & $6.6 \%$ \\
\hline & $\begin{array}{l}\text { Resorption of root equal to } \\
\text { filling material }\end{array}$ & 14 & $93.3 \%$ & 14 & $93.3 \%$ & 14 & $93.3 \%$ \\
\hline & $\begin{array}{l}\text { Resorption of root less } \\
\text { than filling material }\end{array}$ & 0 & $0 \%$ & 0 & $0 \%$ & 0 & $0 \%$ \\
\hline & Pvalue & & & & . & & \\
\hline
\end{tabular}

${ }^{*}$ Chi-square test was applied to determine the success rate between two groups

Table 4 - overall success of groups $1 \& 2$

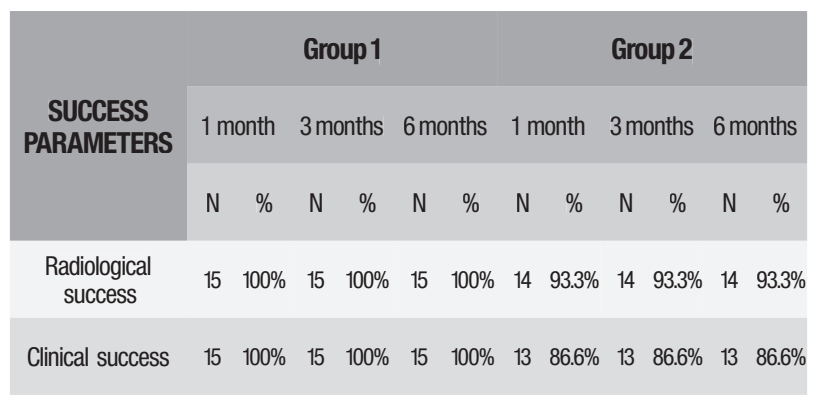

Table 5 - Resorption of overfilled material

\begin{tabular}{|c|c|c|c|c|c|c|}
\hline \multicolumn{7}{|c|}{ Resorption of overfilled material } \\
\hline \multirow{2}{*}{$\begin{array}{l}\text { Immediate postopera- } \\
\text { tive- over-filled material } \\
\text { present }\end{array}$} & \multicolumn{3}{|c|}{$\begin{array}{c}\text { n (Group-1) } \\
\%\end{array}$} & \multicolumn{3}{|c|}{$\underset{\%}{\text { n(Group-2) }}$} \\
\hline & \multicolumn{3}{|c|}{$\begin{array}{c}6 \\
(40 \%)\end{array}$} & \multicolumn{3}{|c|}{$\begin{array}{c}1 \\
(6.6 \%)\end{array}$} \\
\hline \multirow[t]{3}{*}{$\begin{array}{l}\text { At Follow-up period } \\
\text { presence of over-filled } \\
\text { material }\end{array}$} & $\begin{array}{c}1 \\
\text { month }\end{array}$ & $\begin{array}{c}3 \\
\text { months }\end{array}$ & $\begin{array}{c}6 \\
\text { months }\end{array}$ & $\begin{array}{c}1 \\
\text { month }\end{array}$ & $\begin{array}{c}3 \\
\text { months }\end{array}$ & $\begin{array}{c}6 \\
\text { months }\end{array}$ \\
\hline & $n(\%)$ & $n(\%)$ & $n(\%)$ & $n(\%)$ & $n(\%)$ & $n(\%)$ \\
\hline & $\begin{array}{c}0 \\
(0 \%)\end{array}$ & $\begin{array}{c}0 \\
(0 \%)\end{array}$ & $\begin{array}{c}0 \\
(0 \%)\end{array}$ & $\begin{array}{c}1 \\
(6.6 \%)\end{array}$ & $\begin{array}{c}1 \\
(6.6 \%)\end{array}$ & $\begin{array}{c}1 \\
(6.6 \%)\end{array}$ \\
\hline Pvalue & & 0.006 & & & 0.399 & \\
\hline
\end{tabular}




\section{DISCUSSION}

In many primary root canal infections where pulpectomy is the treatment of choice, mechanical preparation and irrigation alone cannot eliminate all the bacteria from the infected root canal,in addition to irrigating root canals, quality of theobturating material used for root canal filling also determines the prognosis of these endodontically treated primary teeth. In the teeth indicated for pulpectomy, for complete disinfection of the root canal, use of appropriate obturating material is essential [10].

$\mathrm{ZOE}$ is one of the most widely used root canal filling material for primary teeth pulpectomies, but the disadvantages include necrosis of cementum and bone, variation in resorption rate of $\mathrm{ZOE}$, or slow resorption in comparison to root resorption [11].Colland Sadrian [12], Bewaziret al. [13] found that ZOE extruded extraradicularly was resorbed slowly and might need several months or even years. Similarly, in the present study, therewas retention of the overfilled material in one toothat the end of $6^{\text {th }}$ month follow up in the zinc oxide eugenol(ZOE) Group 2.

In turn, currently,Endoflas is the next most acceptable material that meets most of the ideal requirements of an obturating material [10]Fuks et al. [14] reported 70\% success clinically with Endoflas and radiographically 100\% decrease in periapical radiolucency. High clinical and radiographic success of Endoflas shows its excellent healing capabilities (54.8\% complete bone healing). But it has a disadvantage of causing tooth discoloration and periapical irritation due to eugenol component [14] Wright et al. [15] reported that iodoform based root canal filling materials show cytotoxic effects and eugenol component present in the Endoflas show hypersensitivity or allergic reactions when it comes in contact with soft tissue [16]. In order to overcome some of these limitations with Endoflas, a new herbal curcumin was tried asan alternative to liquid component eugenol as obturating material for primary teeth. Most of the literature related to Curcumin for endodontic purpose were invitro studies where curcumin was used either as irrigating solution or intracanal medicament. Our invivo studyis the first to explore Curcumin gel mixed Endoflas powder as obturating material for primary teeth in children.

Curcumin, a component of turmeric mainly responsible for its biological activities is a polyphenolic compound, strongly inhibits bacterial cell proliferation and shown to have a potent antibacterial activity against a number of pathogenic bacteria including Enterococcus. Curcumin exhibits anti-inflammatory, antioxidant, anticarcinogenic, antiviral and antimicrobial activity [17].Garima Sharma et al. conducted a study to determine the synergistic antimicrobial potential of curcumin with cinnamaldehyde, eugenol, and ellagic acid against $\mathrm{S}$. Epidermidis, results showed that both curcumin and cinnamaldehyde disrupted the bacterial membrane and killing the bacteria as determined by permeability studies on Escherichia coli[18].

In asystematic review conducted on the safety and anti-inflammatory activity of Curcumin concluded that Curcumin was considered to be safe in six human trials and has demonstrated potent anti-inflammatory activity. Curcumin may exert its anti-inflammatory activity by inhibition of different molecules that play a role in inflammation [19]

In an invitro study that investigated the anti-bacterial potential of curcumin against standard strains of common endodontic bacteria concluded that curcumin has the potential to be developed into a medicament for the treatment of various endodontic diseases [20]. In the present studyCGE Group,clinical success was observed in all the 15 teeth at the end of 1-month follow-up and maintained until the $6^{\text {th }}$ month follow-up. Also, radiographically there was a decrease in inter radicular radiolucency in 8 teeth (6 teeth at the end of 1-month follow-up and 2 teeth at the end of $3^{\text {rd }}$-month follow-up) in Curcumin gel mixed Endoflas group (CGE) exhibiting its medicinal properties. 
In a case series reported by Radha Krishna et al. ,Curcumin gelmixed with Endoflas powder as obturating material exhibited faster resorption of the over pushed material within 1week followup, also showed a decrease in inter-radicular radiolucency after 1month and maintained until the 3rdmonth follow-up [21].The results in the present study were in accordance with these results showing complete resolution of interradicular radiolucency and resorption of the overfilled material by the end of 6months in Curcumin Gel mixed Endoflas powder Group depicting 100\% radiological success rate.

When Endoflas was used as an obturating material,Ramar and Mungara [5] reported a success rate of $95.1 \%$, Subramaniam and Gilhotra[10] reported $93.3 \%$ success rate, whereas Fuks et al. [14] observed a lower success rate of $58 \%$ when there was overfilling and $83 \%$ success rate in cases with flush and under-filled root canals. Iodoform a constituent of Endoflas was found to have excellent healing properties with resorption of the excess material,thereby delivering a success rate of 84-100\%[5].whereas, Gupta et al. [22] in their study showed that among two cases with excess filling material with Endoflas, by the end of 6 months, only one case showed resorption of excess filling material. The time taken for the resorption of inadvertently extruded Endoflas has varied between 20-day and 11-month period inthis study.

In the present study, Group 1 showed 100\% clinical and radiological success rate, which may be attributed to the combination of bactericidal propertyof Iodoform, a component in Endoflas powder [23] and anti-inflammatory activity of the Curcumin Gel. The results showed high success rate with Curcumin Endoflas mixture, overcoming the shortcomings of Endoflas eugenol combination like periapical irritation at the end of the $6^{\text {th }}$-month follow-up, thereby suggesting its useas an alternative material for obturation of primary teeth.

Limitations of the present studyweresmall sample size, unequal distribution of radiological inclusion criteria between the two groups and inclusion of upper primary molars as they are difficult to interpret radiographically.Future studies are recommendedforinclusion oflarge sample size and Endoflas alone as a control group withlong-term follow up periods to determine its impact on root resorption and the success rate of this novel combination of Curcumin Gel mixed Endoflas powder obturating material.

\section{CONCLUSION}

Within the limitations of the current study, Curcumin Gel mixed Endoflas powder as obturating material in primary molars has demonstrated good clinical and radiographic success. Thus,Curcumin Gel mixed Endoflas powder (CGE)combination can be suggested as an alternative to available obturating materialsfor primary teeth.

\section{REFERENCES}

1. Guidelines on pulp therapy for primary andyoung permanent teeth. Pediatr Dent. 2004;26(7 Suppl):115-9.

2. Silva LA, Leonardo MR, Oliveira DS, Silva RA,Queiroz AM, HernándezPG, et al.. Histopathological evaluation of root canal filling materials for primary teeth. BrazDent J.2010 Jan;21(1):38-45.

3. Antoniazzi BF,Pires CW, Bresolin CR, Weiss RN, Praetzel JR. Antimicrobial activity of different filling pastes for deciduous tooth treatment. Braz Oral Res. 2015;29:1-6. Epub2014 Dec 2.

4. Khairwa A, Bhat M, Sharma R, Satish V, Maganur P, Goyal AK. Clinical and radiographic evaluation of zinc oxide with aloe vera as an obturating material in pulpectomy: an in vivo study. J Indian Soc Pedod Prev Dent. 2014 JanMar;32(1):33-8. doi: 10.4103/0970-4388.127051.

5. Ramar K, Mungara J. Clinical and radiographic evaluation of pulpectomies using three root canal filling materials: an in-vivo study. J Indian Soc Pedod Prev Dent. 2010 Jan-Mar;28(1):25-9. doi:10.4103/0970-4388.60481.

6. Erausquin J, Muruzabal M. Root canal fillings with zinc oxide eugenol in rat molars. Oral Surg Oral Med Oral Pathol. 1967 0ct;24(4):547-58.

7. Chawla HS, SetiaS, Gupta N, Gauba K, Goyal A. Evaluation of a mixture of zinc oxide, calcium hydroxide, and sodium fluoride as a new root canal filling material for primary teeth. J Indian Soc Pedod Prev Dent. 2008 Jun;26(2):53-8.

8. Kumar H. An in Vitro evaluation of the antimicrobial efficacy of Curcuma longa, Tachyspermumammi, chlorhexidinegluconate, and calcium hydroxide on Enterococcusfaecalis. J Conserv Dent. 2013 Mar;16(2):144-7. doi:10.4103/09720707.108197.

9. Suvarna R, BhatSS,Hegde KS. Antibacterial Activity of Turmeric against Enterococcus faecalis - An InVitro Study.IntJ CurrMicrobiol AppSci. 2014;3(2):498-504.

10. Subramaniam P,Gilhotra K. Endoflas, zinc oxide eugenol and metapex as root canal filling materials in primary molars--a comparative clinical study. JClin Pediatr Dent. 2011Summer;35(4):365-9. 
11. Chonat A, Rajamani T,Ephraim R. Obturating materials in primary teeth-a review, research and reviews. Res Reviews J Dent Sci. 2018;6(1):20-5.

12. Sadrian R, Coll JA. A long-term follow-up on the retentionrate of zinc oxide eugenol filler after primarytooth pulpectomy. Pediatr Dent. $1993 \mathrm{Jul}-$ Aug;15(4):249-53.

13. Bawazir OA, Salama FS. Clinical evaluation of root canal obturation methods in primary teeth. Pediatr Dent. 2006 Jan-Feb;28(1):39-47.

14. Fuks $A B$, Eidelman E, Pauker N. Root fillings with Endoflas in primary teeth:a retrospective study.J Clin Pediatr Dent 2002 Fall,27(1):41-5.

15. WrightKJ, Barbosa SV, Araki K, Spångberg LS. In vitro antimicrobial and cytotoxic effects of KRl paste and Zinc Oxide Eugenol used in primary tooth pulpectomies. Pediatr Dent. 1994 Mar-Apr;16(2):102-6.

16. Deshpande A, Verma S,Macwan C. Allergic Reaction Associated with the use of Eugenol Containing Dental Cement in a Young Child. Austin J Dent. 2014;1(2):1007.

17. Chamele J,Bhat C. Efficacy of turmeric extract as an intracanal medicament in deciduous teeth against Enterococcus faecalis: An in vitro study. IntJCurrMicrobio|AppSci.2014;3(9):17-25.
18. Sharma G, RaturiK, Dang S, Gupta S,Gabrani R.Combinatorial antimicrobial effect of curcumin with selected phytochemicals on Staphylococcus epidermidis. J Asian NatProd Res. 2014;16(5):535-41. doi: 10.1080/10286020.2014.911289. Epub2014 Apr 29.

19. Chainani-Wu N. Safety and anti-inflammatory activity of curcumin:a component of turmeric (Curcuma longa).J Altern Complement Med. 2003 Feb;9(1):161-8.

20. MandroliPS,BhatK. An in Vitro evaluation of antibacterial activity of curcumin against common endodontic bacteria. J App Pharm Sci.2013;3(1):106-8. doi:10.7324/JAPS.2013.31018

21. Radhakrishna A, Menni A,Prasad M, Chandrasekhar S. The success rate of endoflas powder mixed with curcumin gel as obturating material in primary molars: case-series. J Biomed Pharmac Res [Internet].2017;6(2):100-6.

22. GuptaB, Singh I, Goyal P, Garg S, Gupta S. A Clinical and Radiographic Study of Four Different Root Canal Filling Materials in Primary Molars-An In Vivo Study. Dent J Adv Stud. 2019;1;1-5. doi: 101055/s-0039-1692611.

23. Arora R, RawatP,Bhayya DP.A Comparative Evaluation of Antimicrobial Efficacy of Three Endodontic Sealers: EndoflasFS, AH Plus and sealapex against Enterococcus faecalis - an in vitro study. IOSR JDent Med Sci. 2014;13(3):90-3. doi: 10.9790/0853-13349093.

\section{Naga Radhakrishna Ambati}

(Corresponding address)

Associate Professor, Department of Pedodontics\&Preventive Dentistry,

St.Joseph Dental College,Duggirala, Eluru, Andhrapradesh, India.

E-mail: drradhakrishna27@gmail.com

Date submitted: 2019 Feb 13

Accept submission: 2019 Dec 02 